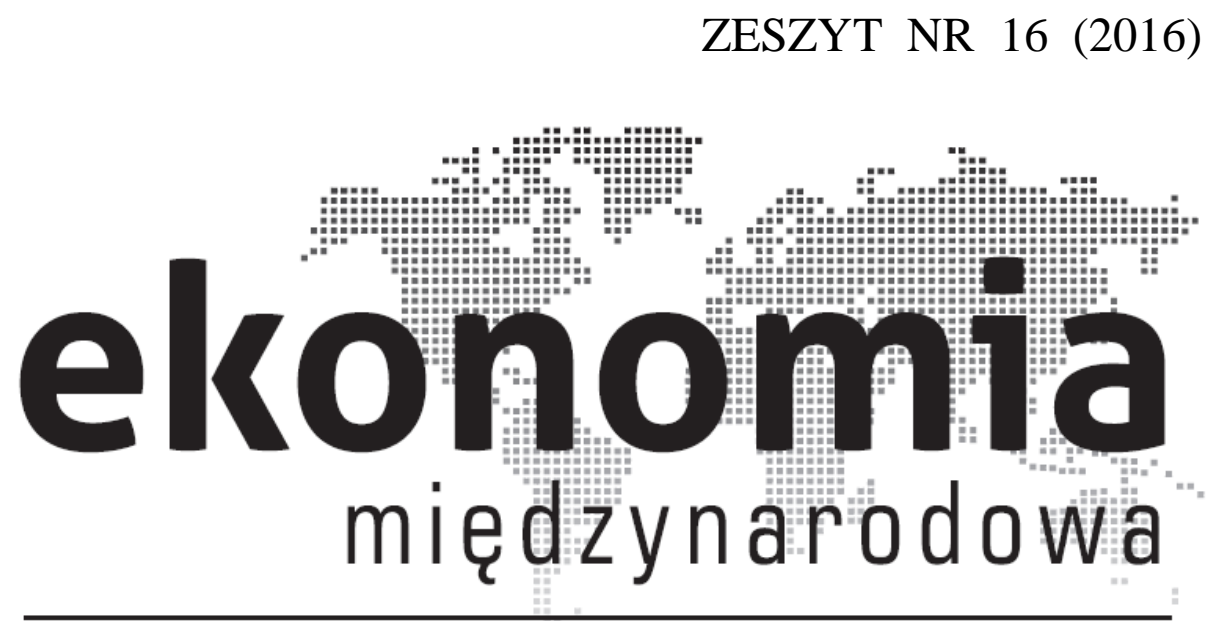

Ekonomia Międzynarodowa

Nr 16 (2016)

www.ekonomia-m.pl

ISSN: 2082-4440

EISSN: 2300-6005

Wydawca: Uniwersytet Łódzki

Wersja elektroniczna czasopisma jest wersją referencyjną
Publisher: University of Lodz

Electronic edition is the reference version of the journal
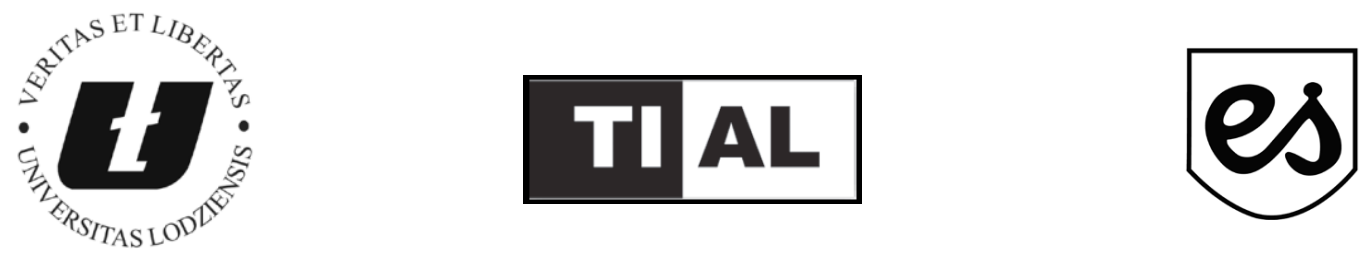


\section{Międzynarodowa pozycja inwestycyjna netto krajów Unii Europejskiej w latach 2006-2014}

Iwona Maciejczyk-Bujnowicz*

\section{Wstęp}

Z teoretycznego punktu widzenia idealnym stanem funkcjonowania poszczególnych gospodarek jest sytuacja, w której saldo bilansu płatniczego wynosi zero. Współcześnie trudno znaleźć przykład gospodarki, w której oszczędności krajowe pokrywają realizowane inwestycje. Taki stan odnosi się do tzw. gospodarki zamkniętej. W gospodarkach otwartych swobodnie przepływający kapitał umożliwia finansowanie inwestycji w przypadku niedoboru kapitału na rodzimym rynku. Dochodzi wówczas do powstania nadwyżki lub niedoboru w saldzie bilansu płatniczego. Ponadto trudno osiągnąć stan równowagi wewnętrznej, tj. między sferą realną a sferą finansową, kiedy w otoczeniu zewnętrznym również jej nie ma. Przepływy kapitału na międzynarodowym rynku finansowym stwarzają możliwości finansowania wzrostu gospodarczego w krajach, w których podaż kapitału nie pokrywa zgłaszanego nań zapotrzebowania. W coraz większym stopniu finansowanie inwestycji odbywa się przy znaczącym udziale kapitału pochodzącego spoza rynku krajowego. Odbywa się to poprzez bezpośrednie inwestycje zagraniczne i/lub kapitał portfelowy i/lub kredyty i pożyczki. Forma zaangażowanego kapitału zależy od wielu czynników. Podstawowymi motywami, którymi kierują się przedsiębiorcy, rozpatrując pozyskanie kapitału na rynkach międzynarodowych, są: dostępność kapitału oraz jego cena, czyli stopa procentowa, będąca wypadkową popytu i podaży kapitału. Ostatni kryzys z lat 2008-2012 ukazał słabe strony postępującej integracji finansowej, także w Unii Europejskiej. Kryzys sektora bankowego dotknął w największym stopniu peryferyjne kraje strefy euro. Celem opracowania jest próba ocenienia zmian

\footnotetext{
* Iwona Maciejczyk-Bujnowicz - doktor nauk ekonomicznych, Uniwersytet Łódzki, Wydział Ekonomiczno-Socjologiczny, Katedra Finansów i Inwestycji Międzynarodowych.
} 
w międzynarodowej pozycji inwestycyjnej netto ${ }^{1}$ w krajach Unii Europejskiej w latach 2006-2014 w kontekście przestrzegania zaleceń w ramach ogłoszonej procedury zakłóceń makroekonomicznych. Dokonano przeglądu najważniejszych koncepcji teoretycznych stanowiących podstawę dalszych rozważań. Aby osiągnąć cel artykułu, przeanalizowano literaturę przedmiotu oraz dane statystyczne odnoszące się do międzynarodowej pozycji inwestycyjnej krajów w latach 2006-2014. Na tej podstawie podjęto próbę ocenienia współczesnych tendencji zachowania się salda netto MPI w UE.

\section{Teoretyczne i empiryczne uzasadnienie przedmiotu analizy}

W badaniach nad kierunkiem przepływu kapitału można wyodrębnić dwa nurty: pierwszy, historyczny, w którym kapitał płynął w stronę krajów biednych z krajów bogatych. Drugi nurt, będący obecnie przedmiotem licznych badań, odnosi się do zmiany kierunku przepływu kapitału, strumień płynie z krajów biednych w kierunku krajów bogatych. Ten współczesny kierunek przepływu kapitału zauważył, jako jeden z pierwszych, Lucas (1990), dlatego zjawisko to zostało nazwane paradoksem Lucasa. Próbę wyjaśnienia tego swoistego fenomenu można rozpoczać od analizy stopnia rozwoju gospodarczego i przepływu kapitału w latach 80 . XX w. W tym czasie średni ważony relatywny dochód krajów wykazujących nadwyżki na rachunku obrotów bieżących był nieco niższy niż krajów mających deficyty na rachunku obrotów bieżących. Zgodnie z podejściem neoklasycznym kapitał przepływa z krajów o relatywnie niższej stopie zwrotu do krajów o relatywnie wyższej stopie zwrotu, zatem różnice w stopie zwrotu pomiędzy krajami powinny determinować przepływy kapitału. Wraz z kolejnymi przepływami następuje wyrównywanie się stóp zwrotu pomiędzy krajami, a poziom związanego z tym nierozłącznie ryzyka jest inny. Odbywa się to m.in. dzięki temu, że kraje, do których następuje napływ bezpośrednich inwestycji zagranicznych netto, doświadczają wzrostu dochodu (Gourinchas i Jeanne 2006). Autorzy twierdzą, że strumień kapitału pomiędzy krajami rozwijającymi się powinien płynąć w większym stopniu do tych, których tempo wzrostu gospodarczego jest szybsze, tj. do tych, których stopa inwestycji jest stosunkowo wysoka.

Warto dodać, że autorzy nie znaleźli dodatniej korelacji pomiędzy napływem kapitału a stopą inwestycji. Na podstawie tych danych (oddzielnie badano Indie i Chiny ze względu na populację), dotyczących lat 1970-2004, zauważyli, że

\footnotetext{
${ }^{1}$ Międzynarodowa pozycja inwestycyjna jest zestawieniem, które przedstawia stany zagranicznych aktywów i pasywów rezydentów wobec nierezydentów na koniec danego okresu. Różnica pomiędzy wielkością aktywów i pasywów zagranicznych stanowi międzynarodową pozycję inwestycyjną netto i informuje, czy kraj jest wierzycielem, czy też dłużnikiem netto w stosunku do zagranicy.
} 
przepływ kapitału zagranicznego netto następuje w mniejszym stopniu do krajów o relatywnie wysokiej stopie wzrostu względem gospodarek o średniej i niskiej stopie wzrostu gospodarczego. Interesujące jest to, że w latach 2000-2004 Chiny, najszybciej rozwijająca się gospodarka na świecie, wraz z Indiami stały się eksporterami netto kapitału. Autorzy opracowania nazwali to zjawisko zagadką alokacji (allocation puzzle). Biorąc pod uwagę dużą dynamikę napływu kapitału do Chin oraz innych krajów rozwijających się w okresie 1970-2004, można stwierdzić, że częściowym wyjaśnieniem tego zjawiska były relatywnie wyższe stopy wzrostu inwestycji oraz relatywnie wysokie stopy zwrotu z inwestycji. Zauważono jednak, że w latach 2000-2004 napływający kapitał netto w formie BIZ nie powodował wyższego, jak dotychczas, tempa wzrostu gospodarczego. Po okresie wzrostu w postaci napływu BIZ do Chin nie absorbowały one później większej ilości napływającego kapitału.

Poszukując wyjaśnienia zachodzących zmian, autorzy licznych badań podejmują próby przeanalizowania tendencji na podstawie licznych badań statystycznych oraz modeli ekonometrycznych. Burnside i Dollar (2000) zbadali na próbie panelowej liczącej 56 krajów zależności pomiędzy napływem kapitału, wzrostem PKB a prowadzoną polityką gospodarczą. Zauważyli, że dodatni i silny wpływ na wzrost gospodarczy miał napływ kapitału zagranicznego do badanych krajów w sytuacji sprawnie prowadzonej polityki gospodarczej oraz rozwiniętego otoczenia instytucjonalnego. Gourinchas oraz Jeanne (2006) uważają, że kraje biedniejsze charakteryzują się relatywnie niższym poziomem dochodu per capita nie z powodu niedoboru kapitału, tylko z powodu ich mniejszej produktywności. A zatem dostęp do zagranicznego kapitału wcale nie musi przekładać się na dodatkowy dochód tych krajów. Aizenman, Pinto i Radziwill (2007) stworzyli na podstawie danych dotyczących lat 90 . XX w. tzw. wskaźnik samofinansowania („self-financing” ratio). Można go interpretować tak, że kraje, w których poziom tego wskaźnika jest wyższy, rozwijają się szybciej w stosunku do tych, w których poziom wskaźnika jest relatywnie niższy.

Autorzy badający zależności między przepływem kapitału a wzrostem gospodarczym są zdania, że należy rozpatrywać jedynie napływ kapitału do gospodarki (inflows) lub pasywa zagraniczne netto, a nie opierać się na przepływach kapitału ogółem w gospodarce. Prasad, Rajan, Subramanian (2006a) przeanalizowali wzajemne zależności między wybranymi kategoriami kapitału zagranicznego a wzrostem gospodarczym. Zgodnie z uzyskanymi przez nich wynikami w krajach rozwiniętych napływ kapitału zagranicznego był dodatnio skorelowany ze wzrostem gospodarczym, a w krajach rozwijających się ten związek był dodatni do pewnego momentu (Grabowski i Maciejczyk-Bujnowicz 2016). Autorzy uznali, że kraje rozwijające się mają ograniczoną zdolność absorpcji kapitału zagranicznego. Gospodarki krajów rozwijających się, których rozwój w dużej mierze zależy od finansowania zewnętrznego, w długim okresie rozwijają się wolniej, niż wynikałoby to z podejścia teoretycznego. W krajach rozwiniętych dzięki 
napływowi kapitału zagranicznego wzrost gospodarczy następuje szybciej. Jeszcze innym aspektem analizowanym w literaturze przedmiotu (Johnson, Ostry, Subramanian 2007), jeśli chodzi o rozpatrywanie zależności pomiędzy napływem kapitału a wzrostem gospodarczym, jest badanie skutków napływu kapitału zagranicznego w odniesieniu do kursu walutowego. Relatywnie wysoki poziom napływu kapitału może wywołać aprecjację waluty, co może zmniejszyć konkurencyjność eksportu dóbr produkcyjnych w krajach rozwijających się, w których wzrost gospodarczy opiera się w dużej mierze na wzroście sektora przemysłowego (Rajan, Subramanian 2005). W efekcie mogą być podejmowane próby ograniczenia napływu do kraju kapitału zagranicznego. Warto podkreślić, że nie znaleziono podobnej zależności w przypadku krajów rozwiniętych.

Z kolei krytycy otwartości przepływów kapitałowych (Bhagwatti 1998, Rodrik 1998, Stiglitz 2000) argumentują, że napływ kapitału zagranicznego może zwiększać ryzyko powstawania wahań w gospodarce. Dlatego kraje te powinny być zainteresowane ograniczeniem napływu kapitału do gospodarki do poziomu, który nie zagrażałby stabilności gospodarczej (Kose et al. 2006) i przyśpieszyłby wybuchu kryzysu finansowego. Prasad, Rajan Subramanian (2006b), zgodnie z podejściem zastosowanym w badaniu Kose et al. (2006), zbadali zależność między otwartością finansową, mierzoną za pomocą wskaźnika integracji finansowej de facto, tj. sumą zasobów aktywów i pasywów, względem PKB czy między przepływami finansowymi a PKB w latach 1970-2000. Przeanalizowano powiązania między średnim wzrostem a miarą restrykcyjności przepływów kapitału de jure (Chinn-Ito), średni poziom (zasób) aktywów i pasywów zagranicznych brutto do PKB, średni poziom napływu BIZ netto oraz współczynnik korelacji zaproponowany przez Feldsteina-Horiokę (1980). Feldstein-Horioka interpretują silną korelację między krajowymi oszczędnościami a krajowymi inwestycjami jako ograniczoną integrację $\mathrm{z}$ międzynarodowym rynkiem finansowym. Zatem w krajach rozwijających się, w których poziom współczynnika korelacji jest niski, powinny one podlegać głębszemu procesowi integracji finansowej z rynkiem międzynarodowym oraz powinny się szybciej rozwijać. Na próbie krajów rozwijających się w okresie 1970-2000 uzyskali nieistotny i niski poziom współczynnika bliski zeru.

Inni badacze (Cardarelli, Elekdag i Kose 2009) zidentyfikowali tzw. epizody odnoszące się do napływu kapitału prywatnego netto w 8 krajach rozwiniętych i 44 rozwijających się w okresie 1987-2007. Za epizod uznali przypadek, w którym napływ kapitału był znacząco i istotnie wyższy niż wykazany trend napływu kapitału do danego kraju. Zauważyli, że w badanym okresie wystąpiły dwie fale napływu kapitału do gospodarek rozwijających się; były to późne lata 80 . (1987-1998) i połowa lat 90. XX w. Jednak autorzy zwracają uwagę na trzecią falę napływu - rozpoczęła się ona w 2002 r. i zakończyła 4 lata później - pod względem skali napływu kapitału była najwyższa. Podczas pierwszej zauważalnej fali dominującymi regionami, do których napływał kapitał, były rozwijające 
się kraje Azji oraz kraje Ameryki Łacińskiej. Fale druga i trzecia odnosiły się raczej do krajów rozwijających się z kontynentu europejskiego oraz pozostałych krajów rozwijających się. Zdaniem autorów opracowania największe zagrożenia dla stabilności funkcjonowania krajów dotyczą tych państw, które cechują się napływem znacznej ilości kapitału oraz nie zachowują równowagi, jeśli chodzi o obroty bieżące. Mody i Murshid (2011) zwrócili także uwagę na znaczenie zmiennej instytucjonalnej. Autorzy badania są zdania, że napływ kapitału do krajów rozwijających się może nie przyczyniać się do ich wzrostu gospodarczego, może ten wzrost osłabiać, a nawet obniżać. Na podstawie omówionych wyników badań można stwierdzić, że w większości z nich uzyskano dodatnie zależności między napływem kapitału zagranicznego a wzrostem gospodarczym w krajach rozwijających się.

\section{Globalne tendencje w przepływach kapitału na podstawie MPI}

W dobie postępującej globalizacji finansowej zauważono znaczące zmiany w strukturze bilansów płatniczych i międzynarodowej pozycji inwestycyjnej badanych krajów. Kraje Azji i Środkowego Wschodu zanotowały dynamiczny wzrost nadwyżek finansowych. W przypadku pozostałych krajów rozwijających się zauważono znaczący wzrost kapitału udziałowego w pasywach ogółem oraz silną akumulację rezerw walutowych. Ogólnie rzecz ujmując, od lat 70. i 80. XX w. następuje dynamiczny wzrost udziału pasywów w PKB krajów rozwiniętych. W ostatniej dekadzie XX w. i na początku XXI w. bardzo dynamicznie wzrastał udział kapitału o charakterze udziałowym w PKB. Od lat 70. do 2004 r. wskaźnik EQI wzrósł o ok. 40 pp. (z poziomu ok. 5\% PKB do ok. 45\% PKB) w krajach rozwiniętych, a w krajach rozwijających się wzrost wyniósł ok. 20 pp. (z poziomu ok. $10 \%$ PKB do ok. $30 \%$ PKB). Interesujący jest fakt, że od lat 70. ubiegłego wieku do ok. połowy lat 80 . w badanej grupie gospodarek rozwijających się udział kapitału udziałowego w strukturze kapitału ogółem drastycznie spadł (o ok. 50\%) z poziomu ok. 35\% do poziomu średnio 16-18\%. W krajach bogatych spadek ten był nieco łagodniejszy (ok. 10 pp.) i osiągnął średnio poziom ok. $25 \%$ pasywów. Od lat 90 . w przypadku obu grup krajów można zauważyć wysokie tempo wzrostu kapitału udziałowego w strukturze kapitału.

Na przełomie XX i XXI w. zaszły dalsze znaczące zmiany w zewnętrznej pozycji inwestycyjnej w gospodarce światowej. W latach 2007-2014 (rysunek 1) można zauważyć ogólną poprawę salda rachunku bieżącego na świecie, wzrost z poziomu ponad 283 mld USD netto $\mathrm{w} 2007 \mathrm{r}$. do poziomu 438,7 mld USD netto w 2012 r. Saldo rachunku finansowego bilansu płatniczego także wyraźnie się poprawiło (wzrost z poziomu ponad 299 mld USD netto w 2008 r. 418,9 mld USD netto w 2014 r.). Skumulowane światowe zobowiązania wobec bezpośrednich 
inwestycji zagranicznych netto wzrosły z poziomu ponad -10,06 mld USD netto w 2009 r. do poziomu ponad -501 mld USD netto w 2013 r. Pozostałe inwestycje netto przebiegały w przeciwnym kierunku wobec bezpośrednich inwestycji zagranicznych. Nastąpił wzrost z ponad -584 mld USD w 2009 r. do ponad 476 mld USD w 2014 r. Inwestycje portfelowe netto cyklicznie się zmieniały - z poziomu 302 mld USD w 2009 r. do -278 mld USD, aby następnie osiągnąć poziom dodatniego salda w wysokości ponad 152 mld USD w 2012 r.

Rysunek 1. Wybrane wskaźniki finansowe z bilansu płatniczego na świecie w latach 2007-2014

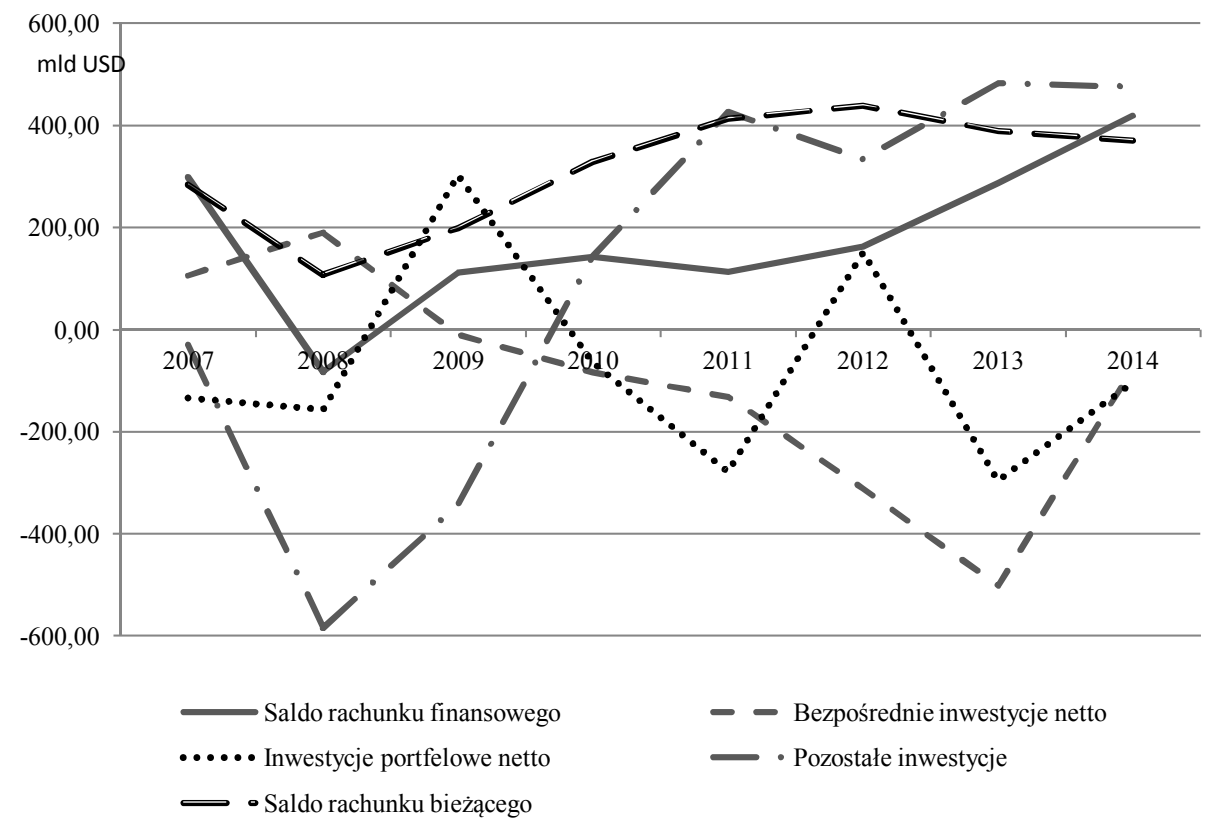

Źródło: opracowanie własne na podstawie IMF.

W krajach rozwijających się Azji i Środkowego Wschodu nastąpiła poprawa zewnętrznej pozycji inwestycyjnej, a w europejskich krajach rozwijających się zmieniła się struktura kapitału. Zewnętrzna pozycja inwestycyjna wobec PKB krajów uznanych za rozwinięte wzrosła, z wyższym relatywnie wzrostem zobowiązań (Australia, Hiszpania, Stany Zjednoczone) oraz większym relatywnie wzrostem aktywów (Japonia, Szwajcaria).

Inni badacze (Faria et al. 2006) dokonują, w wyniku analizy przekrojowo-czasowej gospodarek, wyboru czynników określających strukturę pasywów międzynarodowej pozycji inwestycyjnej krajów w podziale na państwa o wysokim dochodzie i pozostałe państwa. Autorzy uważają, że od lat 70. do połowy lat 80. w badanych krajach udział pasywów ogółem w PKB był na bardzo zbliżonym poziomie, tj. od ok. $25-30 \%$ do ok. $50 \%$ PKB. Od ok. połowy lat 80 . kraje 
bogate charakteryzują się dużo wyższym poziomem udziału pasywów w PKB (w 2004 r. ponad 140-procentowy udział pasywów w PKB) w porównaniu z pozostałymi krajami (ok. 60\% PKB). Gruić (2013) podjął próbę określenia determinant międzynarodowej pozycji inwestycyjnej wybranych krajów w świetle postępującej globalizacji finansowej. Dane obejmują dane kwartalne za okres 1997-2004. Badania dotyczą grupy krajów będących członkami UE, ale nienależących do strefy euro: Czech, Węgier, Polski, Słowacji, Słowenii, Bułgarii, Chorwacji oraz Rumunii. W artykule dokonano dekompozycji międzynarodowej pozycji inwestycyjnej netto badanej grupy krajów. Autor stwierdza, że poziom aktywów i pasywów zależy zarówno od czynników krajowych, jak i zagranicznych. Wśród nich można wymienić: otwartość handlową, wielkość kraju, stopień rozwoju rynku kapitałowego oraz stopień liberalizacji finansowej. Dodatkowo za wyższym stopniem integracji mierzonej kapitałem udziałowym w badanym okresie przemawia fakt relatywnie dużego udziału przedsiębiorstw państwowych poddawanych sukcesywnie prywatyzacji, co skutecznie zachęcało inwestorów zagranicznych do lokowania kapitału udziałowego, zarówno w postaci BIZ, jak i kapitału portfelowego.

Catao wraz z Milesim-Ferrettim (2013) podjęli próbę wyłonienia determinant kryzysów zewnętrznych, zwracając szczególną uwagę na rolę pasywów zagranicznych oraz ich strukturę. Badanie obejmuje lata 1970-2011, dotyczy 70 krajów, spośród których 41 należy do krajów rozwijających się. Autorzy zauważyli, że gwałtownie wzrasta ryzyko kryzysu w danej gospodarce, gdy poziom pasywów zagranicznych netto przekracza $50 \%$ PKB i oscyluje pomiędzy $50-60 \%$ PKB, a także wtedy, gdy wielkość MPI netto wobec PKB przekroczy poziom $20 \mathrm{pp}$. powyżej historycznego średniego poziomu danego kraju. W wyniku przeprowadzonego badania zauważono, że prawdopodobieństwo wystąpienia kryzysu finansowego wzrasta, gdy zwiększa się relatywnie udział długu wobec kapitału udziałowego w pasywach zewnętrznych kraju. Taka sytuacja szczególnie dotyczy krajów, których udział długu netto w pasywach przekracza poziom ok. 35\% PKB. Ryzyko wystąpienia kryzysu jest mniejsze, gdy wzrasta udział netto BIZ w strukturze kapitału. To spostrzeżenie jest zgodne $\mathrm{z}$ wynikami badań przeprowadzonymi przez Hausmanna, Fernandeza-Ariasa (2001) oraz Borenszteina et al. (1998), z których wynika, że rosnący relatywnie udział BIZ w pasywach MPI danego kraju ma pozytywny wpływ - im jest on wyższy, tym dany kraj jest bardziej stabilny i oceniany przez potencjalnych inwestorów jako bezpieczniejszy dla lokowanego kapitału (good cholesterol). Jeśli chodzi o wpływ portfela składającego się z kapitałów udziałowych (portfolio equity) na ryzyko wybuchu kryzysu, to wyniki badań okazały się niejednoznaczne.

Ogólnie rzecz biorąc, z dekompozycji zewnętrznej pozycji inwestycyjnej netto badanych krajów na kapitał udziałowy netto oraz dług netto wynika, że zmienna długu netto pasywów jest najistotniejszą determinantą zewnętrznej pozycji inwestycyjnej netto, która wywiera istotny wpływ na ryzyko wystąpienia kryzysu. 


\section{Ocena międzynarodowej pozycji inwestycyjnej netto (MPI) w krajach Unii Europejskiej w latach 2006-2014}

W minionym dziesięcioleciu w UE doszło do znacznych zakłóceń równowagi makroekonomicznej (które spowodowały nasilenie negatywnych skutków kryzysu finansowego trwającego od 2008 r.) oraz do poważnego zróżnicowania konkurencyjności (które uniemożliwiło skuteczne stosowanie wspólnych środków polityki pieniężnej) ${ }^{2}$. Aby identyfikować i korygować takie zakłócenia równowagi makroekonomicznej na znacznie wcześniejszym etapie, ustanowiono nową procedurę nadzorczo-wykonawczą: ,,procedurę dotyczącą zakłóceń równowagi makroekonomicznej" (Macroeconomic Imbalance Procedure). Procedura dotycząca zakłóceń równowagi makroekonomicznej to mechanizm nadzorczo-wykonawczy mający na celu zapobieganie zakłóceniom równowagi makroekonomicznej w UE i ich korygowanie ${ }^{3}$. Procedura ta ma zapobiegać zakłóceniom równowagi makroekonomicznej w państwach członkowskich i korygować je, ze szczególnym uwzględnieniem tych zakłóceń, które grożą rozprzestrzenieniem się na inne państwa członkowskie.

Do przewidzianych wskaźników, które podlegają okresowej kontroli i weryfikacji, należy wskaźnik dotyczący relacji międzynarodowej pozycji netto względem PKB. Jego wysokość określono na poziomie maksymalnym -35,0\%. Po jego przekroczeniu dokonywana jest pogłębiona analiza przyczyn oraz kierowane są zalecenia do poszczególnych gospodarek w celu ich poprawienia, aby potencjalnie zapobiec powstawaniu zakłóceń grożących stabilności funkcjonowania gospodarki UE jako całości. Może to oznaczać próbę optymalizacji wartości wskaźnika odnoszącego się do międzynarodowej pozycji netto. Warto jednak zauważyć, że mechaniczna ocena bezpieczeństwa gospodarczego makroekonomicznego - pomijając aspekt, że jest on jednym z wielu parametrów oceny - jedynie na podstawie wysokości może budzić wątpliwości. Należy podkreślić, że prowadzone są intensywne badania nad znaczeniem i kierunkami przepływu kapitału dla gospodarek w kontekście jego wartości. Ważne jest także poszukiwanie odpowiedzi na pytanie o występowanie związków między napływem kapitału do gospodarki oraz nie mniej ważną strukturą jego napływu, co ostatnio jest także wyraźnie podkreślane przy analizie jego wpływu na poszczególne gospodarki (Maciejczyk-Bujnowicz 2015).

\footnotetext{
${ }^{2}$ Te zalecenia zapobiegawcze przewidziane w procedurze dotyczącej zakłóceń równowagi makroekonomicznej to część zaleceń, które Rada kieruje w lipcu każdego roku do poszczególnych państw członkowskich w ramach europejskiego semestru.

${ }^{3}$ Art. 3 Traktatu o Unii Europejskiej (TUE), art. 119, art. 121 oraz art. 136 Traktatu o funkcjonowaniu Unii Europejskiej (TFUE).
} 
Tabela 1. Międzynarodowa pozycja netto krajów Unii Europejskiej w latach 2006 art. 2014 (\%)

\begin{tabular}{|c|c|c|c|c|c|c|c|c|c|}
\hline & 2006 & 2007 & 2008 & 2009 & 2010 & 2011 & 2012 & 2013 & 2014 \\
\hline Belgia & 34,3 & 33,6 & 51,7 & 57,3 & 65,1 & 60,8 & 51,7 & 51,6 & 57,2 \\
\hline Bułgaria & -58 & $-81,1$ & $-98,4$ & $-101,8$ & $-95,6$ & $-85,2$ & $-79,8$ & -75 & $-73,4$ \\
\hline Czechy & $-30,9$ & -37 & $-38,2$ & -44 & $-46,1$ & $-45,3$ & $-46,1$ & $-41,5$ & $-35,6$ \\
\hline Dania & $-0,3$ & $-5,8$ & $-5,1$ & 0,9 & 12,9 & 28 & 36,7 & 38 & 47 \\
\hline Niemcy & 19,8 & 18,8 & 18,2 & 25,1 & 25,8 & 23,4 & 28,8 & 34,9 & 42,3 \\
\hline Estonia & $-73,3$ & $-71,3$ & $-75,4$ & $-80,1$ & $-71,2$ & $-55,6$ & -52 & $-47,6$ & $-43,6$ \\
\hline Irlandia & $-19,8$ & $-25,3$ & $-87,7$ & $-107,3$ & -104 & $-127,8$ & $-131,5$ & $-127,6$ & $-106,7$ \\
\hline Grecja & $-81,5$ & $-91,8$ & $-73,7$ & -86 & $-96,7$ & $-84,9$ & $-108,9$ & $-122,2$ & $-124,1$ \\
\hline Hiszpania & $-65,8$ & $-78,1$ & $-79,3$ & $-93,8$ & $-89,1$ & $-91,4$ & -89 & $-94,5$ & $-94,1$ \\
\hline Francja & 1,1 & $-1,5$ & $-13,8$ & $-14,8$ & $-9,3$ & $-8,7$ & $-12,9$ & $-17,5$ & $-19,5$ \\
\hline Chorwacja & $-76,4$ & $-92,1$ & $-74,9$ & $-87,6$ & $-95,6$ & $-92,3$ & $-90,2$ & $-88,5$ & $-88,6$ \\
\hline Włochy & $-21,9$ & $-23,1$ & $-23,6$ & $-24,9$ & $-23,4$ & $-21,9$ & $-26,6$ & $-28,8$ & $-27,9$ \\
\hline Cypr & 37,8 & 11,7 & $-80,1$ & $-101,7$ & $-113,2$ & $-132,6$ & $-128,7$ & $-136,4$ & $-139,8$ \\
\hline Łotwa & $-64,2$ & $-69,2$ & $-74,1$ & $-82,4$ & $-81,9$ & $-74,4$ & $-66,8$ & $-65,1$ & $-60,9$ \\
\hline Litwa & -48 & $-54,6$ & $-51,5$ & $-58,4$ & -56 & $-52,6$ & $-53,4$ & -47 & $-46,4$ \\
\hline Luksemburg & 21,7 & $-18,8$ & 16,6 & $-29,6$ & $-20,8$ & 29,4 & 35,5 & 36,1 & 36 \\
\hline Węgry & $-95,5$ & $-88,9$ & $-102,7$ & $-116,1$ & $-109,4$ & $-106,7$ & $-94,4$ & $-84,1$ & $-73,8$ \\
\hline Malta & 27,9 & 21,6 & 4,2 & 12,6 & 12,1 & 7,9 & 21,3 & 20,8 & 39,5 \\
\hline Niderlandy & $-2,3$ & $-15,4$ & $-8,5$ & 0,9 & 10,6 & 19,8 & 31,1 & 32,3 & 60,8 \\
\hline Austria & $-12,9$ & $-9,8$ & $-10,1$ & $-5,1$ & $-5,2$ & $-1,9$ & $-3,1$ & 1,3 & 2,2 \\
\hline Polska & $-45,1$ & $-49,3$ & -56 & $-57,8$ & $-65,4$ & $-62,9$ & $-65,9$ & $-68,7$ & $-68,3$ \\
\hline Portugalia & $-79,3$ & $-88,8$ & $-95,1$ & $-107,9$ & $-104,3$ & $-100,7$ & $-113,4$ & $-115,7$ & $-113,3$ \\
\hline Rumunia & -36 & $-48,5$ & $-54,1$ & $-64,1$ & $-66,2$ & $-68,5$ & $-70,4$ & $-62,4$ & $-57,2$ \\
\hline Słowenia & $-16,8$ & $-25,5$ & $-39,4$ & $-43,6$ & $-47,2$ & $-45,2$ & $-49,9$ & $-45,8$ & $-43,7$ \\
\hline Słowacja & $-53,5$ & $-51,5$ & $-58,4$ & $-66,7$ & $-62,3$ & $-64,9$ & $-62,2$ & $-63,8$ & $-69,4$ \\
\hline Finlandia & $-12,4$ & $-25,9$ & $-2,5$ & 6,4 & 19,7 & 15,1 & 11,8 & 5,4 & $-0,7$ \\
\hline Szwecja & $-12,3$ & $-1,4$ & $-1,5$ & 0,6 & 2,9 & $-10,2$ & $-14,3$ & $-15,1$ & $-6,5$ \\
\hline Wlk. Brytania & $-14,1$ & $-12,1$ & 4,8 & $-15,3$ & $-8,1$ & $-7,5$ & -21 & $-14,2$ & $-25,3$ \\
\hline
\end{tabular}

Źródło: opracowanie własne na podstawie danych Eurostat. 
W 28 krajach Unii Europejskiej występuje duże zróżnicowanie międzynarodowej pozycji inwestycyjnej netto (tabela 1). Średni poziom dla wszystkich gospodarek wyniósł 39,2\% w całym analizowanym okresie. Można stwierdzić, że jedynie w 12 krajach Unii Europejskiej w latach 2006-2014 nie został przekroczony próg $-35 \%$. Są to: Belgia, Dania, Czechy, Niemcy, Francja, Włochy, Luksemburg, Malta, Niderlandy, Austria, Szwecja oraz Wielka Brytania. Czechy zbliżyły się w 2014 r. do poziomu $35,6 \%$. W pozostałych 16 krajach ujemne saldo międzynarodowej pozycji inwestycyjnej było znacznie wyższe od wymaganego progu 35\%. Do gospodarek, których MPI netto względem PKB było najwyższe i przekroczyło przynajmniej w jednym z badanych lat poziom 100\%, można zaliczyć: Irlandię (-131,5\% w 2012 r.), Grecję, Cypr (-139,8\% w 2014 r.), Węgry oraz Portugalię. Warto podkreślić, że Belgia (średnio w okresie 51,5\%) oraz Niemcy (średnio w okresie 26,3\%), Dania (w okresie 20092014 średnio 27,2\%) oraz Malta (średnio w okresie 18,7\%) w całym badanym okresie wykazywały dodatnią pozycję MPI. W przypadku danych zawartych w tabeli 1 bardzo trudno określić tendencje oraz kierunek zmian w pozycji MPI netto. W niektórych gospodarkach ulegają dalszemu zwiększeniu już i tak dodatnie pozycje netto MPI. W innych przypadkach ujemne wartości pozycji netto MPI pogłębiają się.

W wyniku kompleksowej analizy wskaźników w ramach ujawnionych zakłóceń równowagi makroekonomicznej (w tym MPI netto) procedury przewidują kierowanie zaleceń do krajów, w których poziom -35\% MPI netto został przekroczony. Komisja Europejska indywidualnie odnosi się do sytuacji każdego kraju w ocenie nieprzestrzegania zalecanego poziomu. Należy jednak dodać, że np. w przypadku Polski w 2014 r. poziom MPI netto wyniósł -68,3\%, czyli wartość wskaźnika była niemal 100\% wyższa (rysunek 2). Dla Komisji istotna jest także - i brana pod uwagę - kompozycja aktywów i pasywów MPI Polski. Ujemna wartość międzynarodowej pozycji inwestycyjnej netto w dalszym ciągu jest relatywnie wysoka, a w 2014 r. doszło do jej dalszego nieznacznego zwiększenia. Pozytywnie oceniono sytuację, w której zadłużenie zagraniczne netto jest stosunkowo niższe niż międzynarodowa pozycja inwestycyjna netto, a znaczną część zobowiązań względem zagranicy stanowią bezpośrednie inwestycje zagraniczne, których udział wyniósł w 2014 r. 44\%. Bezpośrednie inwestycje zagraniczne uważane są bowiem za najbardziej stabilny element wszystkich zobowiązań. Warto podkreślić, że gospodarki Unii Europejskiej oceniane są kompleksowo, tzn. przy uwzględnieniu pozostałych wskaźników w ramach procedury dotyczącej zakłóceń równowagi makroekonomicznej (Macroeconomic Imbalance Procedure). 
Rysunek 2. Średnia MPI netto dla krajów UE w latach 2006-2014

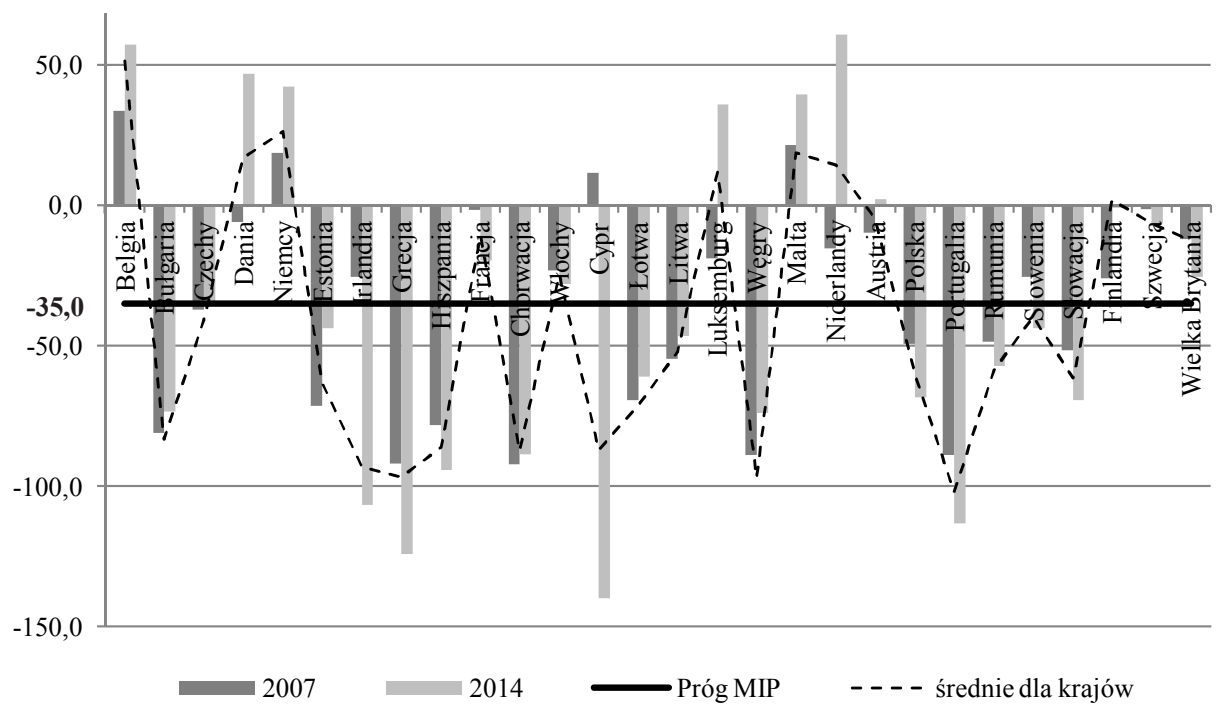

Źródło: obliczenia własne na podstawie danych Eurostat.

\section{Podsumowanie}

W artykule przedstawiono podstawowe koncepcje teorii ekonomicznych oraz wybrane badania empiryczne odnoszące się do znaczenia, tendencji oraz potencjalnych zagrożeń związanych z przepływami międzynarodowymi kapitału. Przeanalizowano, a następnie spróbowano ocenić głównie zmiany w pozycji międzynarodowej netto krajów Unii Europejskiej. Na podstawie analizy i zgromadzonych danych statystycznych można stwierdzić, że istnieją znaczące różnice w przepływach kapitału mierzonego międzynarodową pozycją netto. Wybuch kryzysu w 2008 r. wywołał zmiany w tendencji kształtowania się struktury kapitału na podstawie MPI. W okresie 2006-2014 nastąpił wzrost absolutnych wartości aktywów oraz pasywów MPI. W przypadku większości krajów UE pogłębiło się ujemne saldo przepływów finansowych międzynarodowej pozycji inwestycyjnej względem PKB badanych krajów.

\section{Bibliografia}

Aizenman J., Pinto B., Radziwill A. (2007), Sources for Financing Domestic Capital - is Foreign Saving a Viable Option for Developing Countries?, „Journal of International Monetary and Finance", Vol. 26, No. 5. 
Bhagwati J. (1998), The Capital Myth: The Difference between Trade in Widgets and Dollars, „Foreign Affairs”, Vol. 7, No. 3.

Borensztein E., De Gregorio J., Lee J.-W. (1998), How Does Foreign Direct Investment Affect Economic Growth?, ,Journal of International Economics”, Vol. 45.

Burnside C., Dollar D. (2000), Aid, Policies and Growth, „The American Economic Review", Vol. 90, No. 4.

Cardarelli R., Elekdag S., Kose M.A. (2009), Capital Flows: Macroeconomic Implications and Policy Responses, IMF Working Paper, WP/09/40.

Catao A.V., Milesi-Ferretti G.M. (2013), External Liabilities and Crises, IMF Working Paper No. 13/113.

Faria A., Lane P.R., Mauro P., Milesi-Ferretti G.M. (2006), The Shifting Composition of External Liabilities, IIIS Discussion Paper No. 190.

Feldstein M., Horioka Ch. (1980), Domestic Savings and International Capital Flows, „Economic Journal”, 90/358.

Gourinchas P.-O., Jeanne O. (2006), Capital Flows to Developing Countries: the Allocation Puzzle, NBER Working Paper No. 13602.

Grabowski W., Maciejczyk-Bujnowicz I. (2016), Verification of the hypothesis „too much finance” in the Polish economy, „Central European Review of Economics and Finance", Vol. 11, No. 1.

Gruić B. (2013), Determinants of international investment position, Croatian National Bank, Zagreb.

Hausmann R., Fernandez-Arias E. (2001), Is Foreign Direct Investment a Safer Form of Financing?, „Emerging Markets Review”, Vol. 2, No. 1.

Johnson S., Ostry J., Subramanian A. (2007), The Prospects for Sustained Growth in Africa: Benchmarking the Constraints, IMF Working Paper, WP 07/52.

Kose M.A., Prasad E., Rogoff K., Wei S.-J. (2006), Financial Globalisation: A Reappraisal, NBER Working Paper No. 12484.

Lucas R. (1990), Why Doesn't Capital Flow from Rich to Poor Countries, „American Economic Review", No. 80.

Maciejczyk-Bujnowicz I. (2015), Changes in capital flows in process of integration of the European Union - selected aspects [w:] Sokołowski J., Węgrzyn G., Rękas M. (red.), Prace Naukowe Uniwersytetu Ekonomicznego we Wrocławiu, nr 401, Wrocław.

Mody A., Murshid A.P. (2011), Growth from International Capital Flows: The Role of Volatility Regimes, IMF Working Paper 11/90.

Prasad E., Rajan R., Subramanian A. (2006a), Patterns of International Capital Flows and their Implications for Economic Development, referat zaprezentowany podczas sympozjum ,The New Economic Geography: Effects and Policy Implications", Federal Reserve Bank of Kansas City, Jackson Hole, Wyoming, 24-26 sierpnia $2006 \mathrm{r}$.

Prasad E., Rajan R., Subramanian A. (2006b), Foreign Capital and Economic Growth, IZA Discussion Paper No. 3186. 
Rajan R., Subramanian A. (2005), What Undermines Aid's Impact on Growth, „American Economic Review”, Vol. 88, No. 3.

Rodrik D. (1998), Who Needs Capital-Account Convertibility?, Essays in Interantional Finance, No. 207, Princeton, NJ: Princeton University.

Stiglitz J. (2000), Capital Market Liberalization, Economic Growth, and Instability, „World Development”, Vol. 28, No. 6.

TFUE, Traktat o Funkcjonowaniu Unii Europejskiej (wersja skonsolidowana), Dz. Urz. UE z dnia 26 października 2012 r. C326/01, ze zm.

TUE, Traktat o Unii Europejskiej (wersja skonsolidowana), Dz. Urz. UE z dnia 26 października 2012 r. C326/01, ze zm.

\section{Abstract}

Net international investmnet position of the countries of European Union in the years 2006-2014

The aim of the study is to evaluate changes in the net international investment position in the European Union in the years 2006-2014 in the context of compliance within the framework of the announced process of macroeconomic disturbances. It was reviewed of the most important theoretical concepts. The goal of the article is a critical analysis of the literature of the subject and analysis of statistical data regarding the international investment position of countries for the period 2006-2014. On this basis, it was made an attempt to assess the current movement behavior of the MPI net balance in the EU. In the EU there are significant differences in capital flows measured by the net international position. The outbreak of the crisis in 2008 caused changes in trend in the development of the capital structure in MPI. During 2006-2014 increased the absolute value of the assets and liabilities of MPI. In most EU countries deepens the negative balance of financial flows of international investment position to GDP of the countries.

Keywords: net international investment position NIIP, capital flows

\section{Streszczenie}

Celem opracowania jest próba ocenienia zmian, jeśli chodzi o międzynarodową pozycję inwestycyjną netto ${ }^{4} \mathrm{w}$ krajach Unii Europejskiej w latach 2006-2014 w kontekście przestrzegania zaleceń w ramach ogłoszonej procedury zakłóceń

${ }^{4}$ Międzynarodowa pozycja inwestycyjna jest zestawieniem, które przedstawia stany zagranicznych
aktywów i pasywów rezydentów wobec nierezydentów na koniec danego okresu. Różnica między
wielkością aktywów i pasywów zagranicznych stanowi międzynarodową pozycję inwestycyjną net-
to i informuje o tym, czy kraj jest wierzycielem, czy też dłużnikiem netto w stosunku do zagranicy. 
makroekonomicznych. W niniejszej pracy dokonano przeglądu najważniejszych koncepcji teoretycznych, będących punktem wyjścia dalszych rozważań. W tym celu przeanalizowano literaturę przedmiotu oraz dane statystyczne dotyczące międzynarodowej pozycji inwestycyjnej krajów w latach 2006-2014. Na tej podstawie spróbowano ocenić współczesne tendencje dotyczące salda netto MPI w UE. W krajach UE występują znaczące różnice w przepływach kapitału mierzonego międzynarodową pozycją netto. Wybuch kryzysu w 2008 r. wywołał zmiany w tendencji w kształtowaniu się struktury kapitału w MPI. W okresie 2006-2014 następuje wzrost absolutnych wartości aktywów oraz pasywów MPI. W większości krajów UE pogłębia się ujemne saldo przepływów finansowych międzynarodowej pozycji inwestycyjnej względem PKB badanych krajów.

Słowa kluczowe: międzynarodowa pozycja inwestycyjna netto MPI, przepływy kapitału

JEL: F210, F320, F400 